\section{DIGITAL COMMONS @ UNIVERSITY OF SOUTH FLORIDA}

\section{ABO: Interactive Journal for Women in the Arts, 1640-1830}

Volume 9

Issue 1 Special Issue: Eighteenth-Century Camp

Article 1

2019

\title{
Eighteenth-Century Camp Introduction
}

Ula Lukszo Klein

Texas A\&M International University, ula.e.klein@gmail.com

Emily MN Kugler

Howard University, EMNKugler@gmail.com

Follow this and additional works at: https://digitalcommons.usf.edu/abo

Part of the Dramatic Literature, Criticism and Theory Commons, Educational Methods Commons, Feminist, Gender, and Sexuality Studies Commons, and the Literature in English, British Isles Commons

\section{Recommended Citation}

Klein, Ula Lukszo and Kugler, Emily MN (2019) "Eighteenth-Century Camp Introduction," ABO: Interactive Journal for Women in the Arts, 1640-1830: Vol.9: Iss.1, Article 1.

https://doi.org/10.5038/2157-7129.9.1.1180

Available at: https://digitalcommons.usf.edu/abo/vol9/iss1/1

This Scholarship is brought to you for free and open access by Digital Commons @ University of South Florida. It has been accepted for inclusion in ABO: Interactive Journal for Women in the Arts, 1640-1830 by an authorized administrator of Digital Commons @ University of South Florida. For more information, please contact digitalcommons@usf.edu. 


\title{
Eighteenth-Century Camp Introduction
}

\begin{abstract}
A blend of the silly and the extravagant that puts the serious into conversation with the ridiculous, camp today is often signified by elements of eighteenth-century Europe with its elaborate hairstyles, exaggerated silhouettes, affected courtiers, and a rise in the consumption of exotic goods, candelabras, masks, and other markers of elite excess (often with a nod to the era's demise in the form of either the French Revolution or subsequent Victorian strictures). Camp's relation to queer modes of performance and its prioritization of style over (or in conjunction with) substance offers a queer aesthetic lens to reevaluate the eighteenth century and the current moment. In this special issue on "camp" and/in the long eighteenth century, we hold that this is not just a twentieth-century reference to an imagined past, but a concept that indeed does have its roots in eighteenth-century Europe. It is also a concept deeply rooted in constructions of gender and, whether implicitly or explicitly, a vital element in the lives of long eighteenthcentury female artists, writers, and thinkers. This critical introduction to our special issue on eighteenthcentury camp argues why eighteenth-century camp is a concept both timely and necessary to eighteenthcentury studies, and what these individual essays, and this issue as a whole, contribute to our understanding of the eighteenth century, aesthetics, politics, gender, and sexuality.
\end{abstract}

\section{Keywords}

camp, aesthetics, eighteenth-century, feminism, queer

\section{Creative Commons License}

$$
\text { (c) (1) (8) }
$$

This work is licensed under a Creative Commons Attribution-Noncommercial 4.0 License

\section{Cover Page Footnote}

The authors would like to thank all the participants in the original "Eighteenth-Century Camp" round table at ASECS 2016 in Pittsburgh, PA, for the brilliant conversation that sparked the idea for this issue, as well as the contributors to this special issue and the editors of $A B O$ for being open to hosting it. 


\section{The critical contexts of camp}

Camp is a blend of the silly and the extravagant that puts the serious into conversation with the ridiculous. Today it is often signified by elements of eighteenth-century Europe, with its elaborate hairstyles, exaggerated silhouettes, affected courtiers, and a rise in the consumption of exotic goods, candelabras, masks, and other markers of elite excess (often with a nod to the era's demise in the form of either the French Revolution or subsequent Victorian strictures). Camp's relation to queer modes of performance and its prioritization of style over (or in conjunction with) substance offers a queer aesthetic lens with which to re-evaluate the eighteenth century as well as the current moment. In this special issue on "camp" and/in the long eighteenth century, we hold that camp is not just a twentieth-century reference to an imagined past, but a concept that indeed does have its roots in eighteenth-century Europe. ${ }^{1}$ It is also a concept deeply rooted in constructions of gender and, whether implicitly or explicitly, a vital element in the lives of long eighteenth-century artists, writers, and thinkers.

Current popular conceptions of the eighteenth century as a campy era frequently link past excesses to present sexualities. Period films, such as Sofia Coppola's 2006 film Marie Antoinette, with its playful forays into intentional anachronism, might focus on royal plots centered on reproduction and inheritance, but the decadence and privilege of its subjects is secondary to its heavy reliance on camp aesthetics through stylized acting and themes of artifice and consumption, all in a way that locate the joy for the characters and the audience in their embrace of the ridiculous.

Similarly, campy categories - such as macaronis, fops, the Gothic, caricatures, and the cult of sensibility - are discernable in today's self-aware performances of decadence, subversion, and queerness. The fop and macaroni, for example, can be seen as influencers in the popular television reality show RuPaul's Drag Race, which frequently finds its contestants turning to the eighteenth century as a visual marker of camp. ${ }^{2}$ We see this in Season 3, whose winner Raja donned a Vivienne Westwood ensemble inspired by Marie Antoinette, while the second Drag Race All Stars pageant "HERstory of the World" indexed the eighteenth century as a key part of gay history when it offered campy performances of famous historical women, including the aforementioned queen. We also may think of the frequent campy invocations of the eighteenth century through pirates, such as the mascot for Captain Morgan rum or the character of Jack Sparrow in the Pirates of the Caribbean film franchise. These and other performances - full of self-aware artifice and ironyfrequently index the long eighteenth century as a special moment in which the camp sensibility crystallized.

Drawing on the fields of literature, cultural studies, art history, and history, these essays offer a productive lens through which to view the eighteenth century while at the same time illustrating the usefulness of eighteenth-century scholarship to those working on camp and queer theory in more recent eras. These essays analyze the concept of camp critically to understand how changing notions of sex, gender, and sexuality in the eighteenth century worked alongside and in opposition to the queer gender play of the era. Further, the discussion of changing categories in this special issue addresses-implicitly and explicitly-long-term effects on the representations of women, women's bodies, and concepts of femininity. Through the queering lens of camp, our authors approach the notion of eighteenth-century masculinity as specifically positioned in opposition to femininity, even as camp masculinities are defined against and through received notions of the 
feminine. The sensibility of camp is one in which gender categories become muddled and mixed, and cultural indictments of campiness are often leveled against men implicitly due to the feminized gestures of camp. ${ }^{3}$ The issue will also, we hope, appeal to those outside of academia, as these articles foreground topics of general interest, from the influence of camp on fashion, to the continued love of Jane Austen.

The mission of Aphra Behn Online: Interactive Journal for Women in the Arts, 1640-1830 to focus "on gender and women's issues, and all aspects of women in the arts in the long eighteenth century, especially literature, visual arts, music, performance art, film criticism, and productive arts" makes it an ideal space for these essays. The works in this volume consider representations of women and gender in eighteenth-century literature, art, and print culture through the lens of camp. The accessibility and innovativeness of $A B O$ as a peer-reviewed, open access, born-digital journal allows these essays to reach the existing $A B O$ audience and in turn draw new readers (academic and otherwise) to the significance of camp in queer studies, eighteenth-century studies, and how we live today. Further, as journal editor Laura Runge explains, $A B O$ seeks "to provide a space for the investigation of the categories of gender as they shape, inform, and deform categories of race, ethnicity, religion, embodiment, status, class, sexuality, age and other vectors of power" (1).

Examining a genealogy of camp, positioning its history as not just one that references but resides in the long eighteenth century, the essays within this issue represent a range of approaches to the concept of camp that move across eras, as well as concepts of class, gender, and sexuality. Camp, we argue, is key for understanding the histories of gender and sexuality: it allows us to explore the gaps and overlaps between categories like male/female, man/woman, gay/straight, homosocial/homoerotic, and many others. This reading of the ambiguity and binary-challenging nature of campiness owes much to the rise of queer studies, which has emerged over the past decades as a vibrant and rigorous subfield within eighteenth-century studies. It has provided new insights into well-known topics, such as transnational and empire studies, disability studies, thing theory, and material and visual studies, among others, and has offered new perspectives to eighteenth-century scholars.

Although predating the mainstream scholarly use of the term "queer," Susan Sontag's now-classic essay "Notes on 'Camp" (1964) fits well with the concept of subverting categories of gender and sexuality, emphasizing this mode as tied to discussions of sexuality, particular same-sex desire between men, but also as a way of re-framing seemingly heteronormative texts. ${ }^{4}$ Sontag's piece matters in that it argues for the critical dimension of the term as "one way of seeing the world as an aesthetic phenomenon" (277) and of particular importance to this issue, she observes the presence of this sensibility the early Enlightenment period:

Still the soundest starting point seems to be the late 17th and early 18th century, because of that period's extraordinary feeling for artifice, for surface, for symmetry; its taste for the picturesque and the thrilling, its elegant conventions for representing instant feeling and the total presence of character ... The late 17 th and early 18 th century is the great period of Camp: Pope, Congreve, Walpole, etc., but not Swift; les précieux in France; the rococo churches of Munich; Pergolesi. Somewhat later: much of Mozart. (280) 
Rather serendipitously, the Met Gala theme for 2019 will be an homage to Susan Sontag's foundational camp essay: "Camp: Notes on Fashion," foregrounding the importance of these ideas in our world today. ${ }^{5}$ And although many writers and thinkers have criticized her arguments - in particular, her disengaged, depoliticized, or apolitical stance on camp-her essay began a conversation about this term as one that has the potential to re-focus and de-stabilize our critical understanding on a variety of topics. In queer studies, in particular, its recuperation resonates with arguments on the nature and limits of histories of sexuality.

Still, the history of camp is a history of communities and not simply a methodological tool for cultural interpretation. As a result, some concerns have been raised in queer studies and LGBT studies with regards to the historicization of terms and practices in contemporary queer communities and their application to persons, practices, and identities in the past. Perhaps most notably, David Halperin's How to Be Gay positions "camp" as a twentieth-century U.S. phenomenon in gay male culture, citing that " $\mathrm{t}]$ here is no word for 'camp' in French, German, or Chinese" (17). Although he acknowledges transnational connections between gay communities and notes that there are multiple gay cultures and communities within the U.S., he views camp as fitting within as a distinct set of cultural practices. Drawing on Eve Kosofsky Sedgwick's distinction between "kitsch" and "camp," he describes the latter as "not about attribution, but about recognition," creating a communal bond, specifically between twentieth-century men: "It marks the person making the judgement as an insider ... able to discern camp and that create among such people a network of mutual recognition and complicity. It takes one to know one, indeed-and that, camp implies, far from being shameful, is fabulous" (189). Camp signifies a membership within a specific, and for scholars such as Halperin, temporally and geographically discrete community.

Although aware of such concerns and sensitive to the specific history it has in present-day communities, we believe that use of the term "camp" - a term with a distinctly twentieth-century etymology - can be critically and effectively applied to an earlier time period such as the eighteenth century, and not just because Sontag cites it as the site of the emergence of camp. By expanding this history beyond one group in one century and one nation, we can understand the ways that, as camp became mainstream in the late twentieth-century U.S., it entered into the wider commercial marketplace, as pointed to by Devoney Looser's notion of "vanilla camp." More than this, however, the collected essays in this special issue illustrate how the heyday of Halperin's definition of camp fits into a longer history of sexuality and the continued influence of eighteenthcentury culture. As with other theories that emerged in the twentieth- and twenty-first centuries, camp draws together specific ideas and resonances from the past for the purposes of critical discussion and analysis today.

There is a long-standing precedent for the use of twentieth-century and/or contemporary queer studies terminology in critical approaches to the past. No longer do scholars uniformly insist, for example, on eschewing the term "gay" or "lesbian" in reference to persons living pre-1900. In her introduction to The Apparitional Lesbian, Terry Castle makes light of what she calls the "no lesbians before 1900"" theory, which references Michel Foucault's arguments that "before KrafftEbbing, Havelock Ellis, Sigmund Freud, and others 'invented' the notion of female sexual deviance around $1900 \ldots$ there was no such thing as lesbian identity" (9; 8). Countless scholars since Castle have taken up her arguments with reference to the eighteenth century, specifically, as 
well as other time periods more generally. Recently, in her influential study The Sexuality of History, Susan S. Lanser persuasively argues for the term "lesbian" as both critically and intellectually relevant to early modern studies of history and sexuality, and as one that is "no more historically discontinuous than" other socially-constructed terms such as "slavery, marriage, or family"' (15-16). With careful attention to issues of historicity and accuracy, queer scholars make use of these terms in order to destabilize constructionist notions of sexuality that mark all other time periods as always Other, but also to question essentialist, ahistorical concepts of sexual identities in the past by putting them in conversation with such concepts in the present.

Queering eighteenth-century studies simultaneously calls attention to the shifting paradigms of sexuality. Binaries limit both our concepts of how gender and sexuality were imagined in the past as well as our debates about them today. Summarizing the long-standing debate between essentialist and constructionist views of sexuality in the introduction to their 2007 collection Queer People, Chris Mounsey and Caroline Gonda succinctly contrast the essentialists' "claim that homosexuality is a timeless characteristic, possibly genetically encoded, which can be discovered at any period in history," and the constructionists' view that "sexuality ... is a function of ideology or social pressures, and thus is flexible within and between historical periods" (11). They conclude, as we do, that "neither essentialism nor constructionism necessarily fits the complexities of human sexual and affectional behavior," advocating instead for a merging of approaches when doing queer studies of the past (12).

More recent debates among queer scholars have focused on the teleological and temporal bent to queer historiography while also interrogating the affective connections between queer scholars and their objects of analysis. Valerie Traub's 2013 article "The New Unhistoricism in Queer Studies" analyzes queer scholars' reactions to the essentialist vs. constructionist debate, and the role of historicism in queer studies. Traub argues that one of the most critically influential strands of queer theory of late is the anti-teleological move; that is, the resistance to the idea that "the present [is] a necessary outcome of the past" (21), and relatedly, the push in queer studies to move away from queer identities and to think in terms of temporality and spatiality. In Traub's analysis, however, the rejection of purely identitarian queer politics then results in queer readings emptied of historicist and empiricist rigor. Instead, Traub advocates "to practice a queer historicism dedicated to showing how categories, however mythic, phantasmatic, and incoherent, came to be" (35). The essays in this collection take up these various strands of contemporary debates in queer studies and, through the common thread of camp, suggest how such different readings might cohere around a single term. The entries in this collection consider both the emergence of queer categories of being, such as in the essay by Freya Gowrley on the macaroni, but also how camp reveals the queer constellations of eighteenth-century affects and modes of being, such as in the essays by Julie Beaulieu and Ersy Contogouris. Still other essays suggest the way in which camp can help us mediate the temporal connections between eighteenth-century works and persons with queer identities in our world today, such as in the essay by Devoney Looser.

Our use of the term "camp" to discuss the eighteenth century is one way of mediating between essentialist and constructionist viewpoints, as "camp" itself, despite its twentieth-century nomenclature, draws attention to artifice and the ephemeral gestures of sexuality. Building from Moe Meyer's contribution to queer eighteenth-century studies in The Politics and Poetics of Camp, this issue calls for a queer understanding of camp and, more specifically, how camp has historically 
been connected to queer modes of performance and subjectivity. According to Meyer, "Camp refers to strategies and tactics of queer parody" (9). ${ }^{6}$ By reclaiming "camp" as a queer mode of performance and positioning this definition against Sontag's use of the term and its "appropriation [which] banished the queer from the discourse" (10), Meyer not only redefines the parameters of camp, but also infuses camp with important political meaning. For Meyer, camp can "offer a transgressive vehicle" while also "invok[ing] the specter of dominant ideology within its practice," making it a term uniquely suited to contemporary queer interventions across different disciplines (11). The essays in this special issue take up this idea of camp and its flexibility as a term that draws on Foucauldian and Butlerian notions of the imbricated relationship between the normative and the transgressive. Thus, this seemingly twentieth-century term "camp" functions as a critical concept which allows contemporary scholars to investigate forms of eighteenth-century style, sexuality, and identity.

\section{Why camp? Why now?}

$A B O$ is, however, not just a journal committed to the discussion of the eighteenth-century but first and foremost, it is dedicated to the study of that era's women, as its subtitle articulates: Interactive Journal for Women in the Arts, 1640-1830. In this special issue, concepts of masculinity and male identity are at the forefront of several essays, yet these discussions intersect in important, critical ways with the discourses of female embodiment, gender, and femininity across the eighteenth century. Over the course of the time period encompassed by the purview of $A B O$, notions of sex and gender evolve and change, so that by century's end, gender becomes an entrenched rather than a flexible category of identity, and both gender roles and sexual identity take on an immanence markedly different than their conception in earlier time periods in England. ${ }^{7}$

The history of sexuality in eighteenth-century studies carries its own history of alternatively intersecting with, diverging from, and even occasionally obscuring scholarship on the women of the eighteenth century. In The Sexuality of History, Lanser points to the ways that patriarchal bias at times lingers in sexuality and queer studies, overlooking women from its discussions, but she also reminds us that thinking about how sexual difference is shaped by concepts of gender is neglected in women's studies as well: "The challenge of studying gender and sexuality in tandem is not, however, exclusive to queer studies, for lesbian history has fared little better under the rubric of 'women' than under the rubric of 'queer.' Despite old quips that women's studies is a 'lesbian plot,' seventeenth-and eighteenth-century women's history, at least, remains quite heavily heteronormative" (7). Building upon her observations, we argue that the study of camp offers an avenue for thinking about gender and sexuality in a way that is crucial to understanding the histories of eighteenth-century women. The restrictions and expectations placed on womenboth in historical and creative representations - remain deeply rooted in constructions of gender and sexuality. Camp serves as a category associated with the line between acceptable and outrageous, effeminate deviation and effete performance, and represents the performance of gender and sexuality of women as much as it does of men.

Queer studies and women's studies, at their best, should be in conversation with one another. George Haggerty's Queer Gothic, for example, explores the constructions of sexuality in the gothic in a way that both examines representations of gender within texts and highlights the prominence of women as creators of these texts. Eve Kosofsky Sedgwick's work in sexuality and queer studies 
did not lose sight of questions of women's history, either. Even in her noteworthy Between Men: English Literature and Male Homosocial Desire, the focus on male characters illuminates not only the homophobia latent in these texts (including those authored by women) but also their misogyny.

To study the history of female artists is to think about how the category of "female" is performed by those artists and how that experience fits into a larger discussions of eighteenth-century gender constructions. In its evocation of gender and sexuality, camp walks the line between reveling in the play of binary oppositions and rejecting strict definitions of gender difference. Camp sheds light on the policing of men's affect and dress as "too feminine," and this, in turn, offers a means to study not just the criminalization of sexuality but also how women were defined and limited by these conceptions of gender.

Further, camp is not solely about male gender performances: these essays show that women, too, fit into this history of camp, including those enacting a more masculine persona, those that blurred gender lines, as well as those who drew attention to their own exaggerated performances of femininity. Women, too, enacted their own interpretations of camp, and feature prominently in the essays by Contogouris and Looser. Meanwhile, the essays by Gowrley and Beaulieu discuss eighteenth-century manifestations of masculinity that often drew on received notions of the feminine.

Institutionally, the questions raised by queer and sexuality studies over how we define gender and sex actively shape the identity of women's studies in academia. Women's Studies departments now frequently operate under more inclusive titles, such as Gender and Women's Studies, or Women's, Gender, and Sexuality Studies, or perhaps simply Gender Studies, with "gender" emerging as a means through which to better represent the state of scholarship today. Robyn Wiegman likens the rise of "gender" in Women's Studies to that of "queer in relation to Gay and Lesbian Studies, or trans in relation to queer, or diaspora in relation to both Ethnic and Queer Studies" (40, emphasis original). "Gender" and "queer" operate as "a powerful critique of the ways in which identity, as political project and academic domain, came to be situated in both public politics and the U.S. university" (117). Thus, "queer theory departs from the identity project that most centrally bore it, Gay and Lesbian Studies, to question the constitution of homosexual identity as the primary means for advancing a critical understanding of sexuality" (117). In this light, we offer camp as a critical term that interrogates the identity categories of "woman" and "homosexual" by turning to exaggerated performances of gender and sexuality in the eighteenth century.

\section{Overview of the issue}

Camp possesses the powerful potential to suggest new readings and understandings of literature, art, culture, and historiography through its world-upside-down viewpoint. Collectively, this special issue on camp in the eighteenth century presents a heterogeneous view of sexuality, class, culture, and how we as scholars approach the past.

“Sterne's Sentimental Temptations" by Julie Beaulieu explores our continued attachments to camp sensibility, especially as a gay sensibility ensconced in a bourgeois subjectivity. Beaulieu argues that through the concept of camp, Sterne's use of "excess" takes on new importance, as it "allows us to see how it participates in a larger conversation about acts, identities, and performance." The 
focus on taste within eighteenth-century constructions of sensibility mirrors the importance of taste to definitions of camp. The construction of sentiment as a reflection of bourgeois status, read through the lens of camp, reveals its performative nature that, according to Beaulieu, is critical to understanding "the inherently performative nature of class," as well as the ways in which bourgeois masculinities became increasingly consolidated through appropriate affects and gestures in the eighteenth century.

Picking up on Beaulieu's investigation of class in constructions of sexuality and camp, Ersy Contogouris explores the campy performances of masculinity and femininity at Sir William Hamilton's villa in Naples. In "Neoclassicism and Camp in Sir William Hamilton's Naples," she discusses the evolution of the "Neoclassical" style among the English elites in Italy, and the way in which the mode for all things Neoclassical translated into highly campy performances that engage with and question eighteenth-century notions of Englishness. Contogouris argues that the "attitudes" of Lady Emma Hamilton, as well as the spectacles of young men bathing next to Sir William Hamilton's villa for the visual pleasure of his guests, functioned as "camp spectacles." Contogouris shows that these camp spectacles alter our understanding of the vogue for Neoclassical art and architecture in the eighteenth century, undermining, to a certain extent, their aspirations to seriousness.

Freya Gowrley continues the conversation about camp and style in the eighteenth century in her essay, "Representing Camp: Constructing Macaroni Masculinity in Eighteenth-Century Visual Satire." Gowrley's essay brings the visual component of macaroni and dandyish masculinities to the fore, highlighting the ways in which "late eighteenth-century satirical prints, specifically those featuring images of the so-called "macaroni" function as agents of campiness "that operate not only through their depiction of a Camp subject, but through their very form and function." In this way, Gowrley points to the way the figure of the macaroni fit not only into a history of men's sexuality, but into a larger discussion how such figures act as a "consumable" arguing that "the macaroni was not merely characterized by his love of such trinkets, but that he himself was a trinket" to be possessed or created by both men and women. Her discussion links camp aesthetics to camp consumerism, a notion that Devoney Looser picks up on in her essay as well.

Concluding the issue, Looser's discussion of "Austen Camp" positions Austen and Janeites in opposition to the neoclassical and "serious" camp of Contogouris. Looser argues for a kind of "vanilla camp" that incorporates a sense of naivety and artlessness into its performance. Discussing both the content of Jane Austen's work as well as its pop culture afterlives, this essay points to the way camp plays a vital role in the marketing of the author. Of the essays in this special issue, this piece most overtly links the issues of eighteenth-century camp to the present day, and in doing so, points to the ways that performances of gender, sexuality, and irony enter mainstream capitalism found in the selling of Austen in everything from films to erotica to t-shirts and toothpaste. Looser's argument opens up Austen's work (and we believe, works by other women writers in the long century) to new debates: "No matter where studying Jane Austen camp may lead us next, it seems clear that investigating it both in the originals and in her reception history provides the most fruitful approach. That twin-focus would afford us with opportunities to grasp the potential interconnections of artifice, exaggeration, humor, and social criticism." In doing so, this final essay asks us as readers and scholars to search our own assumptions and methods for determining how we categorize our subjects of study. 
Camp, despite or because of its apparent rejection of seriousness, matters. It is a history that shapes the identity of individuals and communities, and that highlights the histories of marginalization as well as resistance. This topic is also of vital importance to our current historical moment. As university funding, especially for the Humanities, faces cuts, we are asked as scholars to think about how our work connects to the present day. The study of camp links what many may see as a twentieth-century concept to a longer history of style, representation, and sexuality. Without anachronism or over-simplified analogy, the articles in this issue represent the range of innovative work produced by eighteenth-century studies that examines the ways we might think of camp as a history of communities as well as a methodological tool for cultural interpretation.

\footnotetext{
${ }^{1}$ This issue emerged from the 2016 Annual Meeting of the American Society for Eighteenth-Century Studies (ASECS), where we worked to produce new dialogues on the concept of camp by pre-circulating short papers (see 18thCamp.wordpress.com), offering brief overviews by the presenters, and then breaking into working discussion groups on each topic raised. Rather than centering the session on presenters reading papers, the aim of this format was to encourage dialogue that was not limited to the traditional conference Q\&A section. These conversations were something that an academic conference was uniquely suited to do: place people knowledgeable about eighteenthcentury studies in a room together and let that collective knowledge produce a dialogue. In this light, we wanted to continue this conversation on a platform that would offer our presenters and others space to expand on their ideas while still retaining the emphasis on promoting a wider, interdisciplinary conversation within the field of eighteenthcentury studies.

${ }^{2}$ The figuring of the macaroni has been linked to a longer history of same-sex communities, such as in Dominic Janes's Oscar Wilde Prefigured: Queer Fashioning and British Caricature, 1750-1900 and, in this volume, Freya Growerly ties this history of men's fashion explicitly to the performance of camp.

${ }^{3}$ For more on this, see Declan Kavanaugh's Effeminate Years.

${ }^{4}$ For more on this, see Teresa de Laurentis's introduction to the special issue of differences: A Journal of Feminist Cultural Studies (Summer 1991). In it she points characterizes queer theory through her collected essays as work that aims "to expand or shift their semantic horizons and to rethink the sexual in new ways, elsewhere and otherwise. This elsewhere is not a utopia, an otherworldly or future place and time. It is already here, in the essays' work to deconstruct the silences of history and of our own discursive constructions, in the differently erotic mappings of the body, and in the imaging and enacting of new forms of community by the other-wise desiring subjects of this queer theory" (xvi).

${ }^{5}$ The final versions of the essays contained in this special issue were submitted in March 2019, just a few months before that famous May event.

${ }^{6}$ Recently, Max Fincher and Bridget Keegan have used the queer-inflected term of camp in order to analyze Matthew Lewis's Gothic novel The Monk and Romantic laboring-class pastoral poetry, respectively.

${ }^{7}$ See Thomas Laqueur, Karen Harvey, Dror Wahrman, and Susan S. Lanser for more detailed accounts of the ideological changes in the approaches to gender and sex in this time period.
} 


\section{Works Cited}

Castle, Terry. The Apparitional Lesbian: Female Homosexuality and Modern Culture. Columbia University Press, 1993.

de Lauretis, Teresa. "Queer Theory: Lesbian and Gay Sexualities: An Introduction." Special issue of differences: A Journal of Feminist Cultural Studies, vol. 3, no. 2, Summer 1991, pp. iii-xviii.

Fincher, Max. "The Gothic as Camp: Queer Aesthetics in The Monk." Romanticism on the Net: An Electronic Journal Devoted to Romantic Studies, vol. 44, Nov. 2006. https://www.erudit.org/en/journals/ron/2006-n44-ron1433/013997ar/.

Haggerty, George. Queer Gothic. University of Illinois Press, 2006.

Halperin, David. How to be Gay. The Belknap Press of Harvard University Press, 2012.

Harvey, Karen. Reading Sex in the Eighteenth Century: Bodies and Gender in English Erotic Culture. Cambridge University Press, 2004.

"HERstory of the World." RuPaul's Drag Race: All Stars, directed by Nick Murray, World of Wonder, 2016.

Janes, Dominic. Oscar Wilde Prefigured: Queer Fashioning and British Caricature, 1750-1900. University of Chicago Press, 2016.

Kavanagh, Declan. Effeminate Years: Literature, Politics, and Aesthetics in Mid-EighteenthCentury Britain. Bucknell University Press, 2017.

Keegan, Bridget. "Romantic Labouring-Class Pastoral as Eco-Queer Camp." Romanticism on the Net: An Electronic Journal Devoted to Romantic Studies, vol. 36-37, Nov. 2004. https://www.erudit.org/en/journals/ron/2004-n36-37-ron947/011134ar/.

Lanser, Susan. The Sexuality of History: Modernity and the Sapphic, 1565-1830. University of Chicago Press, 2014.

Laqueur, Thomas. Making Sex: Body and Gender from the Greeks to Freud. Harvard University Press, 1990.

Marie Antoinette. Directed by Sofia Coppola, Columbia Pictures, 2006. 
Meyer, Moe. Introduction. The Politics and Poetics of Camp, edited by Meyer, Routledge, 1994, pp. 1-22.

Mounsey, Chris and Caroline Gonda, editors. Queer People: Negotiations and Expressions of Homosexuality, 1700-1800. Bucknell University Press, 2007.

Pirates of the Caribbean. Directed by Gore Verbinski (1-3), Rob Marshall (4), Joachim Ronning and Espen Sandberg (5), performances by Johnny Depp, 2003-2017.

Runge, Laura. "What's in a Name? New Vision for ABO." ABO: Interactive Journal for Women in the Arts, 1640-1830, vol. 7, no. 2, 2017, DOI: http://doi.org/10.5038/21577129.7.2.1170.

RuPaul's Drag Race. Season 3, World of Wonder, 2011.

Sedgwick, Eve Kosofsky. Between Men: English Literature and Male Homosocial Desire. Columbia University Press, 1985.

Sontag, Susan. Against Interpretation and Other Essays. Picador, 1966.

Traub, Valerie. "The New Unhistoricism in Queer Studies." PMLA: Publications of the Modern Language Association of America, vol. 128, no. 1, 2013, pp. 21-39.

Wahrman, Dror. The Making of the Modern Self: Identity and Culture in Eighteenth-Century England. Yale University Press, 2004.

Wiegman, Robyn. Object Lessons. Duke University Press, 2012. 